\title{
Ketokohan Tn. Hj. ‘Abdullah Al-Qari Bin Hj. Salleh ('AQHAS) Sebagai Tokoh Mufassir Tematik Di Malaysia
}

\author{
Personality of Tn. Hj. 'Abdullah al-Qari bin Hj. Salleh ('AQHAS) as Thematic Quranic \\ Interpreter in Malaysia
}

Ahmad Zulfiqar Shah Abdul Hadi, Mohd Abdul Nasir Abd Latif, Muhammad Hasbi Abdul Rahman*

${ }^{a}$ Fakulti Sains Kemanusiaan, Universiti Pendidikan Sultan Idris, Tg. Malim Perak

*Corresponding author: zulfiqar@fsk.upsi.edu.my

\section{Article history}

Received: 2017-12-08 Received in revised form: 2018-01-09 Accepted: 2018-01-12 Published online: 2018-10-31

\begin{abstract}
The Thematic's interpretation of Al Quran (Mawdu'i) is a new approach of Islamic scholars to break through in the context of interpreting al-Qur'an al-Karim, including in Malaysia. One of the writers who wrote vastly in the context of Thematic's interpretation of $\mathrm{Al}$ Quran (Mawdu' $\imath$ ) was $\mathrm{Mr}$. Hj. 'Abdullah al-Qari bin $\mathrm{Hj}$. Salleh (AQHAS). Based on the study, a total of 56 of his works have been produced in the context of the Thematic Interpretation so that he is entitled to be called a Quranic thematic interpreter. Hence, this study is aimed at highlighting information on the interpreter's credibility, the credibility to fulfill his manners and conditions as an interpreter and his works before he can be called an interpreter. In order to achieve this goal, the method of interviews and documentation of related materials are used. The results found that 'AQHAS through his thematic works has benefited the community; a more focused and appropriate understanding of reading for those who want to learn the Quranic knowledge. It is hoped that this information will highlight the personality and accreditation of local scholars in the Quranic interpretation.
\end{abstract}

Keywords: 'Abdullah Al-Qari' Bin Hj.Salleh (AQHAS), Quranic thematic interpreter, Thematic's interpretation, Interpreter's manners and conditions.

\begin{abstract}
Abstrak
Tafsir Tematik (Mawdu’i) merupakan pendekatan baru para sarjana Islam mencebur diri dalam konteks mentafsirkan al-Qur'an al-Karim termasuk di Malaysia. Salah seorang penulis yang banyak menulis dalam konteks Tafsir Tematik ialah Tn. Hj. 'Abdullah al-Qari bin Hj. Salleh ('AQHAS). Berdasarkan kajian, sejumlah 56 buah karya beliau telah dihasilkan dalam konteks Tafsir Tematik sehinggakan melayakkan beliau digelar sebagai mufassir tematik. Justeru, kajian ini dijalankan bertujuan untuk menonjolkan maklumat berhubung biodata tokoh, keupayaan tokoh memenuhi adab dan syarat mufassir dan karya beliau sehingga melayakkan beliau digelar sebagai mufassir. Bagi mencapai tujuan ini, metode temu bual dan metode dokumentasi terhadap bahan berkaitan digunakan. Hasil mendapati bahawa "AQHAS menerusi karya tematiknya telah memberi manfaat kepada masyarakat, kefahaman yang lebih berfokus dan sesuai dijadikan bacaan bagi mereka yang ingin mendalami ilmu al-Qur'an. Diharapkan maklumat ini berjaya menonjolkan ketokohan dan pengikrirafan kepada sarjana tempatan dalam ilmu tafsir al-Qur'an.
\end{abstract}

Keywords: 'Abdullah Al-Qari' Bin Hj.Salleh (AQHAS), Mufassir Tematik, Tafsir Tematik (Mawdu'i), Syarat dan Adab Mufassir 


\subsection{PENGENALAN}

Pentafsiran al-Qur'an merupakan aktiviti ilmiah yang paling diutamakan oleh setiap zaman umat Islam (Ahmad Beely, 1990). Ia amat dititikberat kerana al-Qur'an diturunkan bertujuan menjelaskan tentang konsep hidayah (al-Baqarah : 187), membezakan antara yang benar dan batil (al-Furqan: 1), memberi nasihat dan panduan hidup (Yunus : 57), peringatan kepada manusia (alHijr : 9) dan penyembuh kepada penyakit hati manusia (al-Isra' : 82). Dalam usaha menyampai dan memberikan penerangan ajaran Islam kepada masyarakat, para ulama telah mentafsirkan ayat-ayat al-Qur'an dengan pelbagai metodologi dan pendekatan. Dengan usaha-usaha tersebut lahirlah para mufassir yang terkenal dengan karya tafsir masing-masing yang menjadi rujukan. Antara metodologi pentafsiran al-Qur'an yang digunakai oleh para mufassir dalam karya mereka ialah metode al-mawdu'i. Menurut al-Farmawi (1976), tafsir tematik bermaksud mengumpulkan ayat al-Quran yang mempunyai tujuan yang satu bersama-sama dalam membahaskan tajuk tertentu dan menyusunnya sebaik-baik yang boleh sesuai dengan masa turunnya, selaras dengan sebab turunnya, kemudian memperhatikan ayat tersebut dengan penjelasan, huraian, hubungannya dangan ayat yang lain dan mengeluarkan hukumnya. Tafsir al-Mawdhu'i (tematik) telah banyak diaplikasikan oleh mufassir dalam penulisan kitab tafsir mereka. Antara kitab tafsir kini yang menampilkan gaya metodologi tematik ialah Tafsir Ayat al-Ahkam dan Safwah al-Tafasir karangan Muhammad Ali al-Sabuni, Tafsir al-Munir karangan Dr. Wahbah al-Zuhaily, Tafsir Nur al-Qur'an: An Elightening Commentary into Light of the Holy Qur'an karangan Allamah Kalaml Faqih Imani dan TafsirAhkam al-Qur an karya al-Jassâs (w. 370 H.) Artikel ini secara umumnya memfokuskan kepada sumbangan $\mathrm{Hj}$. Abdullah al-Qari bin Hj. Salleh (AQHAS) menerusi karyakarya sebagai seorang mufassir moden yang menggunakan metode Tafsir al-Mawdhüi. Beliau merupakan anak kelahiran Kelantan yang aktif dalam penulisannya berkaitan dengan tafsir dan pengajian al-Qur'an (Lokman Abdullah, 2004). Walaupun beliau tidak menghasilkan kitab tafsir secara lengkap keseluruhan al-Qur'an, namun sumbangannya dalam bidang ini amat dikagumi (Mustaffa Abdullah, 2009). Ini berdasarkan jumlah buku yang berkaitan dengan tafsir dan pengajian al-Qur'an yang mencecah sejumlah lebih 50 buah buku. Bukunya ini telah menjadi rujukan ramai; masyarakat, pelajar sekolah, pelajar pengajian pondok serta di peringkat pengajian tinggi.

\subsection{METODOLOGI KAJIAN}

Secara umumnya kajian ini adalah kajian kualitatif yang dijalankan secara deskriptif dengan mengguna pendekatan kepustakaan. Segala maklumat yang diperlukan dikumpul oleh pengkaji dan diperolehi dengan menggunakan dua kaedah; iaitu temubual dan dokumentasi. Untuk prosedur temubual, penyelidik telah membuat satu set temubual bersama $\mathrm{Tn}$. $\mathrm{Hj}$. 'Abdullah alQari bin Hj. Salleh yang merangkumi skop berikut: biodata kelahiran, keturunan dan keluarga, latar belakang pendidikan dan pengajian, perkhidmatan dan kerjaya, aktiviti penulisan dalam konteks umum dan khusus kepada bidang tafsir tematik, keperibadian dan akhlak, anugerah dan pencapaian. Manakala untuk dokumentasi, penyelidik telah mengumpul maklumat menerusi dokumen berbentuk penulisan meliputi buku, jurnal, akhbar, majalah dan sebagainya.

Untuk menganalisis semua maklumat, kajian ini telah menggunakan analisis diskriptif iaitu menerusi metode penelitian dokumen dan transkripsi temubual. Untuk menganalisis gaya tafsir tematik yang digunakan, pengkaji telah meneliti semua tulisan dan karya khusus AQHAS yang berkaitan dengan tafsir tematik yang keseluruhannya berjumlah 56 buah. Selain itu, kajian 
perbandingan juga digunakan bagi membuat perbandingan antara syarat dan adab mufassir dengan latar belakang akademik dan keperibadian AQHAS bagi memastikan ia diiktiraf sebagai seorang mufassir.

\subsection{PERBINCANGAN DAN DAPATAN}

Nama penuh AQHAS (عقص) ialah 'Abdullah Al-Qari' Bin Hj.Salleh Bin Abdul Latif Bin Wanik Kenanga Bin Basri. Manakala ibunya Hjh.Khadijah Bt.'Abdullah B.Hj. Abdul Qadir B. Ismail Bin 'Abdullah. Beliau dilahirkan di Kampung Kenali, Kubang Kerian, 5 1/2 kilometer dari Bandar Kota Bharu, Kelantan pada Ahad 23 Syawal, 1356 Hijriyyah bersamaan 26 Disember 1937. Kini beliau sudah berumur 79 tahun (2016). Beliau dibesarkan dalam kehidupan sederhana dan tinggal di tepi Pondok Kubur Tok Kenali dengan mendapat pengaruh pendidikan pondok.

\subsection{Keperibadian}

Beliau seorang yang kecil ukuran tubuh badannya sekitar ketinggian 150 sentimeter dengan badannya yang kurus namun bertenaga. Jika diperhatikan kepada perwatakan, beliau seorang yang bersifat tenang, teliti dan merendah diri semasa berbicara serta peramah. Beliau amat mudah didekati dengan wajah yang sentiasa tersenyum berhati-hati dalam percakapan. Beliau juga seorang yang suka hidup sederhana dan amat jauh dari hidup secara bermewah-mewahan. Selain itu, beliau juga seorang yang kuat azam dan cita-cita. Ini dibuktikan dengan kerjaya beliau sebagai seorang pendidik, pengarang, penerbit dan penda'wah. Beliau seorang yang amat rajin serta tekun dan sabar. Ini terbukti dengan penghasilan jumlah buku yang di luar jangkaan iaitu lebih dari 320 buah buku. Dengan keperibadian dan sifat-sifat inilah yang membuatkan beliau berjaya, disegani dan dihormati segenap lapisan masyarakat terutama penduduk kampung dan mereka yang mengenali beliau.

\subsection{Latar Belakang Pendidikan AQHAS}

AQHAS mendapat pendidikan agama sejak kecil disebabkan bapanya adalah seorang Guru AlQur'an yang terkenal di Pondok Kenali. Sejak kecil lagi AQHAS didedahkan pengajian AlQur'an dan akhlak oleh kedua ibubapa beliau. Berikut diringkaskan latar belakang pendidikan AQHAS:

a) Peringkat rendah: Beliau bermula dengan Sekolah Melayu Kubang Kerian, Kelantan dari tahun 1946 (ketika berumur 9 tahun) sehingga tahun 1951 apabila tamat Darjah Enam dan memperolehi Pangkat Satu. Pada tahun 1952, beliau menyambung pelajaran di Sekolah Melayu Kota (Jelasin) di peringkat darjah tujuh dan berjaya memperolehi Pangkat Satu apabila menamatkan pelajaran.

b) Pendidikan Luar: Di antara tahun 1949-1951, beliau belajar ilmu-ilmu Islam dan bahasa Arab di Pondok Kenali dan Madrasah Ahmadiyyah. Pada tahun 1952, beliau belajar di Pondok Madrasah Al-Ahmadiyyah Bunut Payung pada waktu malam. Selain ilmu-ilmu Islam, beliau juga telah belajar Bahasa Inggeris secara sambilan di Sek. Melayu Kubang Kerian dan di Sek.Umum Padang Garung, Kota Bharu di sebelah malam.

c) Pendidikan Pasca Sekolah: Beliau telah berjaya mendapat Sijil Kursus Persekolahan Melayu atau dikenali dengan 'Trained Under Otherwise Secheme' (T.U.O.S), iaitu sijil perguruan pada tahun 1956. Seterusnya, beliau mengambil peperiksaan untuk 
menjadi guru pakar bahasa dan sastera di Maktab Perguruan Bahasa, (Language Institute) Kuala Lumpur pada tahun 1959 untuk menjadi guru sekolah rendah dan menengah.

d) Peringkat Menengah Atas: AQHAS kemudiannya menyambung pelajaran peringkat menengah di Sekolah Arab Jami’ Merbau, Kota Bharu. Pada tahun 1963 beliau telah menduduki Sijil Persekolah Malaysia (SPM). Pada tahun 1973, beliau mengambil peperiksaan Sijil Tinggi Persekolahan Malaysia (STPM) dan lulus dengan cemerlang.

e) Pengajian Tinggi: Berdasarkan keputusan STPM 1973, AQHAS telah memilih untuk melanjutkan pelajaran ke Universiti Malaya dalam jurusan Pengajian Islam di Fakulti Sastera pada tahun 1974. Beliau memasuki Universiti Malaya semasa usianya 40 tahun (AQHAS: Temubual 8 Mei 2015). Beliau telah menamatkan pelajarannya pada tahun 1977 dengan memperolehi ijazah Sarjana Muda Pengajian Islam (Kepujian) dan mendapat anugerah Mahasiswa Terbaik 1977.

\subsection{Perkhidmatan Kerajaan}

AQHAS merupakan salah seorang yang agak lama berkhidmat dalam bidang pendidikan dan pengajaran iaitu selama 39 tahun (4.1.1953 hingga 26.12.1992). Ia bermula sejak umur beliau ketika itu 15 tahun sehinggalah beliau berpencen pada umur 55 tahun. Secara ringkasnya perkhidmatan beliau dibahagikan kepada dua peringkat iaitu:

Pengalaman Mengajar Di Sek.Rendah:

1. Sekolah Melayu pada tahun 1953

2. Sek. Melayu Pasir Hor,

3. Sekolah Sultan Ismail

4. Sekolah Inggeris Tumpat (G.E.S).

Peringkat Mengajar Di Sekolah Menengah:

1. Sek. Men. Lanjutan Mentuan, Kota Bharu (1962)

2. Sek. Men. Lanjutan Padang Garung, Kota Bharu.

3. Sek. Men Jenis Kebangsaan Chung Hwa (1964 selama 5 tahun)

4. Sek. Men Long Ghafar, Kubang Kerian, Kota Bharu (1969).

5. Pensyarah sambilan mengajar Bahasa dan Sastera Melayu di Pusat Pengajian Tinggi Islam Nilam Puri (1965-1966).

6. Sek. Men Ismail Petra, Kompleks Sekolah-sekolah, Kota

7. Sek. Men Agama ('Arab) Al-Ma’had Al-Muhammadi (Lelaki) pada tahun 19891992

8. Sek. Men Rantau Panjang (1992)

9. Sek. Men. Pengkalan Chepa sehingga bersara pada 26 Disember, 1992 beliau bersara sebagai seorang guru secara formal semasa umur beliau 55 tahun.

Selain itu, beliau juga pernah berkhidmat sebagai pensyarah sambilan mengajar Bahasa dan Sastera Melayu di Pusat Pengajian Tinggi Islam Nilam Puri (1965-1966).

\subsection{Anugerah Dan Pencapaian}

Berdasarkan sumbangan beliau yang besar dalam bidang dakwah, penulisan, pengajaran dan penyelidikan, beliau telah diberi pelbagai pengiktirafan dari pelbagai pihak dari peringkat sekolah 
sehingga ke peringkat antarabangsa. Oleh kerana khidmat cemerlang dan luar biasa ini beliau telah diberi pengiktirafan dengan dianugerahkan sebagaimana berikut:

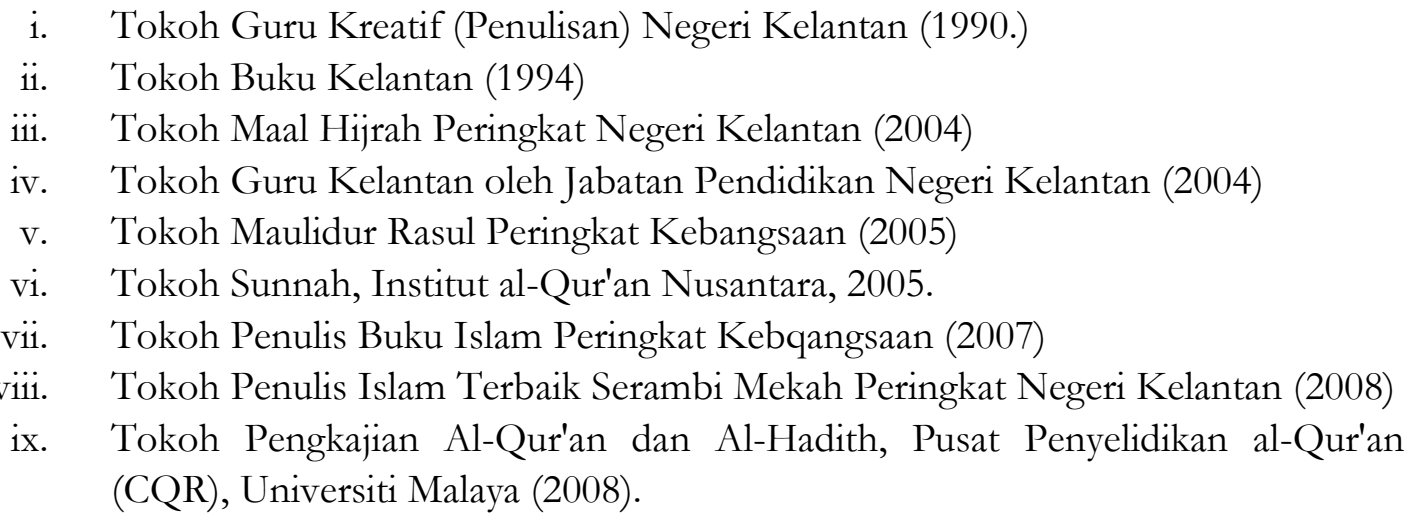

\subsection{PENGLIBATAN AQHAS DALAM BIDANG PENULISAN}

Penglibatan AQHAS sebagai penulis bermula seawal 15 tahun. Beliau menceritakan kisah mimpi yang telah ditunjukkan oleh Allah kepada beliau yang menampakan dirinya mengayuh basikal pergi ke sebuah kedai kitab terbesar di Kota Bharu serta membeli kitab-kitab. Tidak berapa lama selepas itu beliau ditakdirkan bermimpi berhadapan dengan wajah Rasulullah SAW. Dalam mimpi bersama Rasulullah SAW, beliau menceritakan bahawa Nabi SAW telah berkata pada beliau "Anta belajarlah agama anta, Islam". (Abdullah al-Qari, 2006). Jadi bermulalah kehidupan beliau dengan proses membaca majalah, buku dan kitab, serta sibuk mencatatnya menjadi beberapa buku ringkasan ilmu pengetahuan Agama dan Sains dan lain-lain.

Pada tahun 1953 merupakan tahun bersejarah bagi beliau di mana pada tahun itu beliau mula menggalas beberapa tugas penting iaitu menjadi guru, pengarang dan penerbit. Pusat penerbitan yang dibawah kelolaan beliau ini dinamakan "Pustaka ASA" iaitu singkatan kepada Pustaka Angkatan Sayap Al-Islam telah berjaya menerbit dan mengedarkan buku lebih daripada 130 tajuk.

Moto dan semangat beliau menulis boleh dilihat pada potongan kata "AWAS MASAMU" yang memberikan seolah-olah amaran bagi beliau untuk sentiasa menjaga masa. Sehingga kini karya-karya dan terjemahan AQHAS melebihi daripada 300 buah sama ada dalam skala besar atau kecil. Berikut di senaraikan antara kecenderungan atau tujahan tulisan yang telah dihasilkan oleh AQHAS dalam penulisan buku-buku beliau:

1. Pengajian Al-Quran: Khususnya dalam bidang Tajwid menerusi bukunya "Kursus Qari' dan Qari'ab”. Ia adalah sebuah buku yang agak lengkap dan pernah dijadikan buku teks di UKM. Buku ini terbitan Pustaka Aman Press dengan bilangan cetakan sebanyak 31 kali ulang cetak. Dalam bidang pengajian al-Qur'an dilanjutkan lagi dengan beberapa penulisannya yang lain antaranya ialah; Lanjutan Kursus Qari' dan Qariah, Memabami Qa'idah-qa'idah Tulisan Resam Mushaf 'Uthmani, Pengajaran Membaca Qur'an Cara Baru, Keutamaan Penghafal Dan Peminat Al-Qur'an, Bagaimana dan Mengapa Kita Perlu Menghafal AlQur'an? Tilawah Nabi Di Kala Malam dan Kamus Pantas Mencari Surah-surah Al-Qur'an Urutan Turunnya.

2. Pengajian Sunnah dan Hadith: AQHAS juga terkenal sebagai pengarang buku-buku Sunnah menerusi karangan beliau seperti Asas Sembahyang Nabi, Contoh Sembahyang Nabi, Contoh Puasa Nabi, Bagaimana Nabi Berbijrah, Wirid Sembahyang Nabi, Do'a Nabi Selepas 
Sembahyang, 313 Sabda bikmat Warisan Nabi Mubammad SAW dan 50 Anugerah Istimewa Kepada Rasulullah s.a.w.

3. Sejarah Islam: Antara karangan beliau dalam bidang sejarah Islam ialah Mubammad: Rasulullah Makbluk Pilihan dan Rasul Contoh, Riwayat Nabi Mubammad Sejak Kecil Sampai Wafat (4 Penggal), 139 'Amalan Jaahiliyyah Dan Perbandingan Manusia Kini, Menyakini Utusan Allah (Kepimpinan, Peranan Dan Dasar Perjuangan), Jawapan STP Sejarah Islam Zaman Rasulullah SAW dalam Esei dan Politik Pentadbiran Negara Islam Zaman Nabi SAW. Beliau juga menulis tentang sejarah di Malaysia seperti karya beliau tentang Tokoh Ulama Kelantan iaitu Tok Kenali ${ }^{1}$.

4. Bahasa Melayu dan Sastera: Beliau dikenali juga sebagai "Pengarang Buku-buku Peribahasa" dengan lahirnya buku-buku seperti: Peribahasa Kanak-kanak (4 Penggal), Peribahasa Bergambar (4 Penggal), Peribahasa Moden, Peribahasa Peralehan, Pengantar Bahasa Melayu (3 Penggal) dan Perintis Bahasa (3 Penggal). Selain itu dalam konteks bahasa, beliau telah menghasilkan kamus loghat daerah Kelantan dengan nama "Kamus Peraturan Loghat Kelantan”. Perbendaharaan kata dalam buku ini dikumpul dalam masa 20 tahun sejak tahun 1960. Apa yang membanggakan ialah buku ini telah dipilih sebagai buku teks di salah sebuah university di Amerika dan bahan kajian penting di sebuah university di Sulewesi, Indonesia dalam kajian loghat daerah Nusantara.

5. Alam Ghaib: Selain buku-buku 'aqidah maka beliau menulis berkenaan alam ghaib antaranya ialah Sejarah Penciptaan Alam Ghaib Dan Alam Nyata, Sejarah, Tugas Dan Kemampuan Mala'ikat, Meyakini Peranan Mala'ikat dalam Kerajaan Allah dan Kebidupan Manusia, Menyingkap Rabsia Jin, Syaitan dan Mala'ikat (di mana buku ini dicetak rompak di Indonesia), Sejarab Penciptaan Jin - Syaitan dan Cara Menepis Gangguannya dan Barisan Jin Ifrat Dan Gangguannya Menurut Al-Qur'an.

6. Tasawwuf: Beliau menyatakan bahawa beliau juga dikenali dengan aliran tasawwuf sederhana. Ini dibuktikan melalui karangan beliau seperti ; Hakikat Sufi Dan Tariqat Dari Kacamata Al-Qur'an Dan As-Sunnah, Mengembalikan Tasannuf Dan Tariqat ke Pangkalnya, Salab Fabaman Tentang Nur Mubammadi, Menyingkap Fabaman Salah Nabi Kbidr Masib Hidup?, Kedudukan Niyat dan Ikblas Dalam Islam, Penyakit-Penyakit Ikblas Dan Rawatannya, Bagaimana Mencapai Ketenangan Jiwa Dan Kekbusyukan Menurut Islam?, Keseronokan Rub Kembali Menemui Allah (Kekasib), Rahsia Tbadat Hati dan Mertabat Hati dan Hakikat Menuju Allah.

7. Perubatan : Buku-buku beliau dalam bidang ini lebih fokus kepada perubatan Islam iaitu menerusi karyanya Ajaran, Perubatan Dan Pesanan Jibril 'A.S', Atasi Sakit Dengan Urut \& Jampi Sendiri, 239 Penawar Bisa, Racun Dan Keracunan, Ensiklopedia Madu: Rawatan Penyakit Dengan Madu, Ensiklopedia Herba-herba Sekeliling Kita, Panduan Menjampi \& Mengguna Jin Menurut Al-Qur'an Dan Al-Hadith, Rabsia \& Khasiyat Zamzam, Zaitun Dan Tamar - Awet Muda, 121 Ubat Penyembuban Lelah, 474 Khasiyat Perubatan Dan Guna Kelapa dan Himpunan Jampi Perubatan Nabi s.a.w.

8. Bidang Pendidikan: Buku-buku beliau dalam bidang ini lebih fokus kepada Pendidikan Islam iaitu menerusi karyanya seperti Imu Penerang Hati dan Tenaga Pengingat, Dasar-dasar

\footnotetext{
${ }^{1}$ Beliau telah menghasilkan buku-buku tentang Tok Kenali antaranya ialah Sejarah Hidup Tok Kenali (PAP), Detik-detik Sejarah Hidup Tok Kenali, Sumbangan Tok Kenali, Sumbangan Tok Kenali Kepada Dunia Ilmu, Kelantan Serambi Makkah Di Zaman Tok Kenali, Warisan Cerpen Tok Kenali: Tok Qadhi Dan Tok Guru, 12 cerpen Tok Kenali, 10 Sikap Dan Pandangan Tok Kenali, Kekeramatan Tok Kenali dan Pusaka Tok Kenali.
} 
Pendidikan Menurut Islam, Falsafah Pendidikan Menurut Al-Qur'an, Pengajaran Membaca Qur'an Cara Baru, Masalah Merokok Di Kalangan Pelajar-pelajar Dan Belia Islam dan Keharamannya dan Tugas Ibubapa-Guru Terbadap Anak-anak. Menurut Al-Qur'an dan As-Sunnah.

9. Pendidikan Wanita: AQHAS juga dikenali melaui tulisan beliau berkenaan dengan pendidikan wanita. Ini terbukti melalui penulisannya seperti Memilih Jodob Dan Berumahtangga Menurut Nabi s.a.w., Hukum Berbijab Dan Tarbiyahnya Menurut Al-Qur'an. Antara batas-batas 'Aurat Wanita, Zina Mata Dan Pakaian Taqa, Kebangkitan Wanita Islam, Hak dan Kebebasan Wanita Islam, Arah W anita Islam dan Amaran Nabi Kepada Kaum Wanita.

Dalam bidang penulisan, beliau telah menggunakan beberapa nama pena antaranya ialah AQHAS atau dengan jawinya (عقص ) merupakan nama pena yang paling kerap digunakan dan merupakan singkatan nama beliau iaitu Abdullah al-Qari Haji Salleh, Doktor Ruhani kebanyakannya digunakan pada tulisan yang berbentuk keruhanian, Tok Janggut dan Ustadz Chung Hwa khususnya tulisan beliau dalam Mingguan Kota Bharu.

Semasa ditemubual, pengkaji telah dimaklumkan bahawa hampir 100 lagi buku beliau yang akan diterbit dalam pelbagai bidang. Beliau telah menunjukkan rekod fail komputer buku cadangan yang akan dihasilkan untuk masa-masa akan datang.

\subsection{KARYA AQHAS DALAM METODE TAFSIR TEMATIK}

Sa'id (1991) mendefinisikan al-Tafsir al-Mawdu'i sebagai ilmu yang membahaskan tentang permasalahan dalam al-Quran yang mempunyai kesatuan makna ataupun tujuan menerusi pengumpulan ayatnya yang terpisah, kemudian menganalisisnya berdasarkan keadaan tertentu bagi menjelaskan maknanya, mengeluarkan unsur yang dikandungnya serta mengikatnya dengan ikatan yang menyeluruh.

Merujuk kepada pengklasifikasiannya, Rashwani (2009) mengklasifikasikan al-tafsir almawdu'i kepada dua bahagian iaitu menerusi surah al-Quran (al-tafsir al-mawdu'i li al-surab), subjek tertentu (al-tafsir al-mawdu'i li al-Quran). Manakala menurut Al-Khalidi (2001), beliau telah menambah satu lagi bentuuk iaitu tafsir tematik berdasarkan istilah al-Quran (al-tafsir al-mawdu'i li mustalah al-Quran). Namun bila diperhalusi semua karya AQHAS yang berkaitan dengan tafsir, ia telah dibahagikan kepada dua bahagian berbentuk tematik iaitu menerusi surah al-Quran (altafsir al-mawdu'i li al-surah), subjek tertentu (al-tafsir al-mawdu'i li al-Quran) dan yang ketiga ialah karya umum pengajian al-Qur'an. Berikut klasifikasi kesemua karya tafsir tematik yang dihasilkan oleh AQHAS:

\begin{tabular}{|l|l|l|}
\hline Tafsir tematik berdasarkan surah & $\begin{array}{c}\text { Tafsir tematik berdasarkan tema } \\
\text { tertentu }\end{array}$ & \multicolumn{1}{|c|}{$\begin{array}{c}\text { Karya Umum Pengajian al- } \\
\text { Qur'an }\end{array}$} \\
\hline $\begin{array}{l}40 \text { hadith Sekitar Keutamaan al- } \\
\text { Kursiy }\end{array}$ & $\begin{array}{l}\text { Ciri-ciri Mu'min, Kaafir Dan } \\
\text { Munafiq Dalam Al-Qur'an }\end{array}$ & $\begin{array}{l}\text { Bagaimana Dan Mengapa Kita } \\
\text { Perlu Menghafal Al-Qur'an? }\end{array}$ \\
\hline $\begin{array}{l}\text { 74 Hadith Keistimewaan Suurah } \\
\text { Al-Ikhlaash }\end{array}$ & $\begin{array}{l}\text { Sinar Wahyu menembusi Pantun } \\
\text { Falsafah Melayu }\end{array}$ & $\begin{array}{l}\text { Keagungan Kitab Al-Qur'an Dan } \\
\text { Peminatnya }\end{array}$ \\
\hline $\begin{array}{l}\text { Keagungan Ibu Al-Qur'an Dan } \\
\text { Liku-liku Rahsianya }\end{array}$ & $\begin{array}{l}\text { Ciri-ciri Hamba Allah Dalam Al- } \\
\text { Qur'an }\end{array}$ & $\begin{array}{l}\text { Cara Baru Mengajar Tajwid \& } \\
\text { Hafalan Al-Qur'an }\end{array}$ \\
\hline $\begin{array}{l}\text { Surah Tabaarak : Pencegah } \\
\text { Seksaan Kubur }\end{array}$ & Bahaya Syirik menurut al-Qur'an & $\begin{array}{l}\text { Rekod Kegigihan Mengkhatami } \\
\text { Al-Qur'an Di Kalangan Salaf }\end{array}$ \\
\hline Tafsir Surah al-Ikhlas & Penyembuh \& Khasiat Al-Qur'an & \begin{tabular}{l} 
Ibadah Unggul Telinga \\
\hline
\end{tabular} \\
\hline
\end{tabular}

Page | 19 


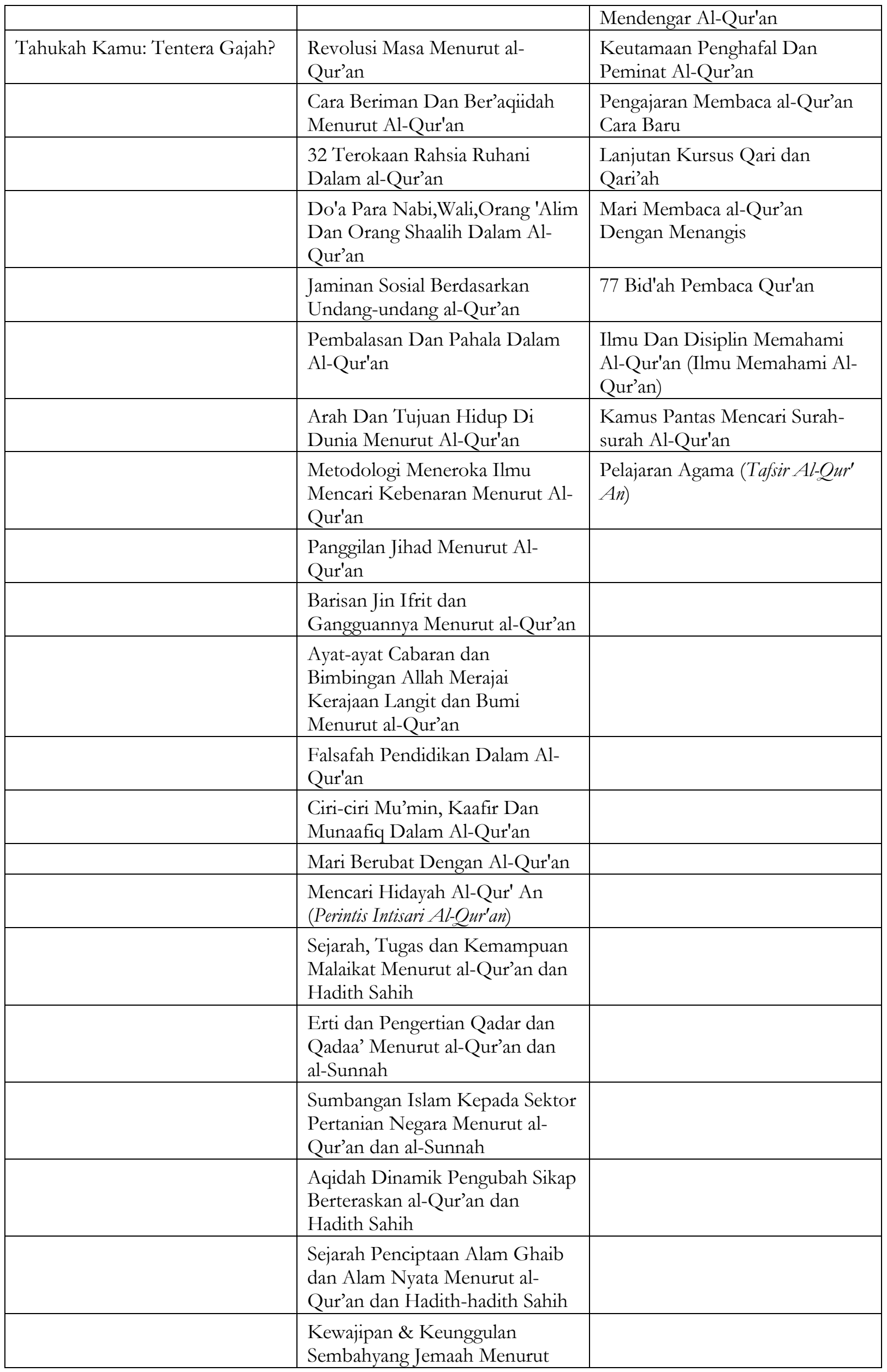




\begin{tabular}{|l|l|l|}
\hline & Al-Qur'an \& As-Sunah & \\
\hline & $\begin{array}{l}\text { Martabat Malu Menurut Al- } \\
\text { Qur'an Dan As-Sunnah }\end{array}$ & \\
\hline & $\begin{array}{l}\text { Panduan Adzaan Dan Iqaamah } \\
\text { Menurut Al-Qur'an \& As-Sunnah }\end{array}$ & \\
\hline & $\begin{array}{l}\text { Panduan Menjampi \& Mengguna } \\
\text { Jin Menurut Al-Qur'an Dan Al- } \\
\text { Hadith }\end{array}$ & \\
\hline & $\begin{array}{l}\text { Ciri Corak Gagasan 'Aqidah Ahlu } \\
\text { As-Sunnah }\end{array}$ & \\
\hline & $\begin{array}{l}\text { Keagungan Kalimah Tauhid Dan } \\
\text { Penghayatannya }\end{array}$ & \\
\hline & $\begin{array}{l}\text { Bacaan Di Hari-hari Akhir } \\
\text { Menghadapi Kematian }\end{array}$ & \\
\hline & $\begin{array}{l}\text { Martabat Ridha Kepada Qadha' } \\
\text { Allah Dan Kepentingannya }\end{array}$ & \\
\hline & $\begin{array}{l}\text { Unsur-unsur Akhlak dalam Al- } \\
\text { Qur'an Dan Kitab-kitab Samawi }\end{array}$ & \\
\hline & Dasar-dasar kepercayaan Islam & \\
\hline & $\begin{array}{l}\text { Memahami dan Meneroka Nur } \\
\text { Cahaya 'Hidayah' Ke Syurga }\end{array}$ & \\
\hline & $\begin{array}{l}\text { Mengenal Syurga Dalam Serba } \\
\text { Keanehan dan Keabadiannya }\end{array}$ & \\
\hline &
\end{tabular}

\subsection{KEWIBAWAAN AQHAS DALAM KEPERLUAN SYARAT DAN ADAB MUFASSIR.}

Al-Harby (1996) menjelaskan definisi mufassir ialah personaliti yang memiliki kemampuan yang tinggi dalam mencapai hakikat maksud Allah Taala dalam Al-Quran besesuain dengan kaedahkaedah (manhaj) mufassir yang digariskan. Menurut Ahmad Bazawy Adh-Dhawy (2006), syarat mufassir secara umumnya terbahagi menjadi dua iaitu aspek pengetahuan dan aspek keperibadian. Dari aspek ilmu pengetahuan, Al-Suyuti (1999) telah menyenaraikan ilmu-ilmu tertentu yang perlu dikuasai untuk melayakkan seseorang itu menjadi mufassir. Setelah dinilai berdasarkan pengamatan, temubual dan tinjauan hasil penulisan AQHAS telah memenuhi keseluruhan syarat yang disenaraikan. Penyesuaian bidang ilmu dengan pencapaian AQHAS boleh disimpulkan sebagaimana berikut:

1. Ilmu Bahasa Arab. Secara umumnya lebih dari 100 karya yang dihasilkan oleh AQHAS merupakan karya terjemahan yang berasal dari bahasa Arab. Dengan keupayaan menghasilkan karya terjemahan ini menunjukkan beliau berkemampuan tinggi dalam memahami segala ilmu nahw, saraf dan balaghah yang terdapat dalam pembelajaran bahasa Arab.

2. Pengajian al-Qur'an. Banyak penulisan dan pencapaian beliau dalam menghasilkan karya al-Qur'an yang pelbagai termasuk karya tafsir, pengajian al-Qur'an dan tajwid al-Qur'an. Ini terbukti melalui antara penulisan beliau seperti Lanjutan Kursus Qari' dan Qariah, Memahami Qa'idah-qa'idah Tulisan Resam Mushaf 'Uthmani, Pengajaran Membaca Qur'an Cara Baru, Keutamaan Penghafal Dan Peminat Al-Qur'an, Bagaimana dan Mengapa Kita Perlu Menghafal Al-Qur'an? Tilawah Nabi Di Kala Malam dan Kamus Pantas Mencari Surah-surah Al- 
Qur'an - Urutan Turunnya. Penghasilan buku-buku ini telah menunjukkan keupayaan dan kemampuan beliau dalam mendalami pengajian al-Qur'an.

3. Usuluddin. Bidang ini merupakan tulisan yang paling banyak dihasilkan oleh AQHAS. Antara penulisan bidang akidah dan tauhid adalah seperti Allab Merajai Kerajaan Langit Dan Bumi, Analisa Dua Kalimab Syabadah \& Sebab-sebab Kufur-Murtad Dan Aktanya Nama Lain: Rabsia Kunci Syurga), Arah Dan Tujuan Hidup Di Dunia Menurut Al-Qur'an, 'Aqidah Dinamik Pengubah Sikap, 'Aqidah Salaf Pegangan Terakhir Imaam Al-Asy'ari, Ciri Corak Gagasan' Aqiidah Ablu As-Sunnah, Dasar-Dasar Kepercayaan Islam, Dekatnya Imam Mahdi Dan Tanda-tanda Nyata Kiamat dan Mertabat Ridha Kepada Qadha' Allah Dan Kepentingannya.

4. Fiqh dan Usul Fiqh. Secara dasarnya tidak banyak karya yang dihasilkan yang membincangkan bidang Fiqh dan Usul Fiqh secara khusus. Namun perbincangan ini diselitkan dalam banyak buku tulisan beliau sama ada pandangan mazhab atau pandangan sahabat yang dijadikan sebagai sumber fiqh dan pendalilan. Berikut disenaraikan bukubuku yang dibincangkan secara tidak langsung berkenaan Fiqh dan Usul Fiqh iaitu Asasasas Sembahyang Nabi (180 Ciri Sembahyang Nabi), Bacaan Para Haji Dan Peng'umrah, Bagaimana Nabi Berbaji Dan Ber'umrah?, Contoh Sembabyang Rasulullah s.a.w. (Contoh Sembahyang Nabi s.a.w.), Hukum Dan Akibah Meninggal Dan Melengah-lengah Sembahyang, Kelebihan \& Rabsia Puasa-puasa Sunat Menurut Sunnab Nabi s.a.w., Kursus Sembabyang Hajat, Istikharah Dan Perkenan Do'a, Mengapa Islam Melarang Merokok, dan Ulasan Kufurnya Orang Meninggalkan Sembahyang dan Mengenepikan Hukum Allah.

5. Hadith dan Mustalah Hadith. Kemampuan beliau dalam ilmu hadith juga terserlah melalui penulisan beliau. Jika diamati dalam karya beliau, kebanyakan hadith yang dijadikan hujah akan disertakan dengan status hadith berkenaan sama ada sahih, hasan atau daif. Beliau juga menulis beberapa karya dalam hadith antaranya ialah Asas Sembahyang Nabi, Contoh Sembahyang Nabi, Contoh Puasa Nabi, Bagaimana Nabi Berbijrah, Wirid Sembabyang Nabi, Do'a Nabi Selepas Sembahyang, 313 Sabda bikmat Warisan Nabi Muhammad SAW dan 50 Anugerah Istimewa Kepada Rasulullab s.a.w.

Selain itu, beliau juga telah menulis beberapa karya dalam menegur masyarakat tentang amalan yang bertentangan dengan sunnah Rasulullah SAW sebagaimana karyanya iaitu Salah Faham Tentang Nur Mubammad, 139 'Amalan Jaabiliyyah Dan Perbandingan Manusia Kini, 72 Sunnah Dan Bid'ah Sekitar Pengurusan Mayat, 77 Bid'ah Pembaca Qur'an dan Memahami Nilai Hadith dan Sunnab Nabi s.a.w.

1. Ilmu-ilmu kontemporari seperti teknologi, pembangunan fizikal dan perubatan. Dari sudut penulisan, tidak ada satu pun tulisan yang membincangkan berkenaan dengan teknologi secara khusus namun dalam buku Sektor Pertanian Negara Menurut al-Qur'an dan as-Sunnah beliau telah membincang secara lansung berkenaan penggunaan mesin dalam proses pertanian. Selain itu, beliau juga telah menghasilkan karya berbentuk perubatan Islam seperti Ajaran, Perubatan Dan Pesanan Jibril 'A.S', Atasi Sakit Dengan Urut \& Jampi Sendiri, 239 Penawar Bisa, Racun Dan Keracunan, Ensiklopedia Madu: Rawatan Penyakit Dengan Madu, Ensiklopedia Herba-herba Sekeliling Kita, Panduan Menjampi \& Mengguna Jin Menurut Al-Qur'an Dan Al-Hadith, Rabsia \& Khasiyat Zamzam, Zaitun Dan Tamar - Awet Muda dan 121 Ubat Penyembuban Lelah

Syarat kedua yang harus dipenuhi pada diri seorang mufassir adalah syarat yang berkaitan dengan aspek keperibadian. Keperibadian adalah merujuk kepada akhlak dan nilai-nilai rubiyyah yang harus dimiliki oleh seorang mufassir agar layak untuk menanggung amanah dalam 
menyingkap dan menjelaskan kandungan al-Quran agar Kalam Allah terpelihara dari sebarang penyelewengan.

Berdasarkan pandangan Imam Al-Suyuti di atas, Ahmad Bazawy Al-Dawy (2006) meringkaskan beberapa adab dan akhlak yang mesti dimiliki oleh seorang mufassir untuk melayakkan mereka mentafsirkan al-Qur'an sebagaimana berikut:

i. Akidah yang lurus.

ii. Bebas dari tindakan berasaskan hawa nafsu.

iii. Niat yang baik.

iv. Akhlak yang mulia

v. Tawadu' (rendah diri) dan lemah lembut

vi. Bersikap zuhud.

vii. Melazimi taubat.

viii. Tidak bersandar pada ahli bid'ah dan kesesatan dalam menafsirkan kandungan al-Quran.

ix. Boleh dipastikan bahawa beliau tidak tunduk kepada akal dan menjadikan alQuran sebagai panduan yang diikuti.

x. Mengamalkan ilmunya dan boleh dijadikan contoh teladan.

xi. Jujur dan teliti dalam penukilan.

xii. Berjiwa mulia.

xiii. Berani dalam menyampaikan kebenaran.

Berdasarkan kepada temubual dan pemerhatian, secara umumnya sifat dan adab yang disenaraikan ini amat bertepatan dengan akhlak dan keperibadian AQHAS. Beliau merupakan orang yang melazimi solat tahajjud, membaca al-Qur'an, puasa sunat maka dengan ini menunjukkan beliau layak dijadikan contoh teladan. Selain itu, kesederhanaan hidup dan zuhud ini tercermin apabila melihat penampilan beliau sama ada berpakaian, rumah kediaman dan kenderaan.

Menerusi temubual yang dijalankan, beliau bercakap dengan nada yang lemah lembut, mesra dan berjiwa mulia. Beliau amat rendah diri dan tidak pernah mendabik dada dengan hasil karya yang banyak bahkan beliau selalu menyebut yang semua kerja beliau ini kerana Allah dan dakwah Islamiah. Ketika ditanya berapakah jumlah karyanya hingga kini, beliau menegaskan yang beliau tidak pernah mengira jumlah sebenar karyanya, bahkan beliau menegaskan untuk menjadi seorang pengarang yang baik, kuantiti bukanlah ukuran tetapi sifat ikhlas diperlukan untuk mendapat bantuan daripada Allah.

Secara umumnya boleh disimpulkan bahawa syarat-syarat mufassir sama ada ilmu pengetahuan dan adab keperibadian jelas menunjukkan kelayakan $\mathrm{Tn} . \mathrm{Hj}$. Abdullah al-Qari $\mathrm{Hj}$. Salleh (AQHAS) digelar sebagai mufassir khususnya mufassir tematik.

\subsection{KESIMPULAN}

Hasil dapatan yang telah diperolehi jelas menunjukkan ketokohan Tn. Hj. Abdullah al-Qari Hj. Salleh (AQHAS) sebagai penulis agong yang dilahirkan di Malaysia. Segala sumbangan beliau sama ada dalam bidang penulisan, dakwah, pengajaran, penyelidikan dan khidmat masyarakat perlu dihargai.

Dengan hasil penulisan yang menjangkau lebih dari 350 buah buku mempamerkan satu pencapaian yang unik dan luar biasa. Setakat pengalaman dan pengamatan pengkaji mengenai 
tokoh ini, belum ada anak Melayu di Malaysia mahu pun di peringkat antarabangsa yang telah menulis buku melebihi jumlah buku yang telah dikarang oleh beliau. Tempoh penulisan yang menjangkau lebih dari 60 tahun, dimanfaatkan dengan sebaiknya untuk ummah. Penulisan beliau yang juga melangkaui pelbagai bidang terutama dalam pengajian Islam ini menunjukkan ketinggian ilmu AQHAS sehinggakan beliau layak digelar ulama mahupun memikul gelaran tuan guru.

Manakala dari sudut gelaran mufassir, beliau amat berkelayakan dan memenuhi kriteria sama ada dari aspek ilmu pengetahuan mahupun keperibadian. Bukti penulisan yang pelbagai bidang, ketekunan dan sifat amanah, keperibadian yang zuhud, merendah diri dan melazimi ibadah sunat, jelas menunjukkan kesesuaian AQHAS diiktiraf sebagai mufassir khususnya mufassir tematik. Beliau tidak pernah mendabik dada dengan hasil karya yang banyak bahkan beliau selalu menyebut yang semua kerja beliau ini kerana Allah dan dakwah Islamiah.

Dengan menonjolkan ketokohan Tn. Hj. Abdullah al-Qari Hj. Salleh (AQHAS) membawa kepada beberapa kesimpulan, di antaranya;

i. budaya mempelajari makna dan tafsir al-Qur'an amat tinggi di Malaysia.

ii. wujudnya mufassir tematik di Malaysia

iii. kebolehan anak Melayu menghasilkan karya pengajian Islam dalam jumlah yang besar

iv. tiada alasan bagi umat Islam di Malaysia tidak mempelajari tafsir al-Qur'an kerana sudah tersedia maklumat dalam bahasa Melayu.

\section{Rujukan}

Abdullah al-Qari Hj. Salleh. (2006). Bagaimana Menulis \& Menterjemah Buku-buku Keislaman Bermutu? Kuala Lumpur: al-Hidayah Publisher.

Ahmed al-Beely. (1990). Konsep Kurikulum Pendidikan Islam. Dalam: Kurikulum dan Pendidikan Guru. Muhammad Hamid al-Afendi dan Ahmed Nabi Baloch. Kuala Lumpur: Dewan Bahasa dan Pustaka.

Adh-Dhawy, Ahmad Bazawy. (2006). Maz̧hab abl a-Sunnah fi al-Tafsir. Morocco : Jami'ah Syu'aib al-Dakali al-Jadidah.

Al-Harbi, Husayn bin Ali. (1417H). Qawa'id al-Tarizh 'Ind al-Mufassirin. Riyadh: Dar al-Qasim.

Al-Khalidi, Salah 'Abd al-Fatah. (2001). al-Tafs'ir al-Mawdu'i Bayn al-Nazariyyah wa al-Tatbiq, Jordan: Dar alNafa'is.

Al-Suyuti, Jalal al-Din Abd al-Rahman bin Abi Bakr. (1999). Al-Itqan fi Ulum al-Qur'an. Tahqiq: Muhammad Abu al-Fadl Ibrahim. Bayrut: Maktabah al-'Asriyyah.

Farmawi al-, Abd al-Hayy. (1977). Al-Bidayah al-Tafsir al-Mawdu'i. Kaherah: Matba’ah al-Hadarah alArabiyah.

Lokman Abdullah. (2004). Abdullah al-Qari Haji Salleh Sebagai Pengarang dan Penterjemah yang Paling Produktif di Malaysia. Latihan Ilmiah, Pusat Pengajian Jarak Jauh, USM.

Mustaffa Abdullah. (2009). Khazanah Tafsir di Malaysia. Kuala Lumpur: Akademi Pengajian Islam, Universiti Malaya.

Rasywani, Samir Abd al-Rahman. (2009). Manhaj al-Tafsir al-Mawdu'i li al-Qur'an al-Karim. Syria: Dar alMultaqa.

Sa'id, 'Abd al-Sattar Fath Allah. (1991). Al-Madkhal ila al-Tafsir al-Mawdu'iy. Kaherah: Dar al-Tawzi' wa alNasyr al-Islamiyyat.

Page | 24 